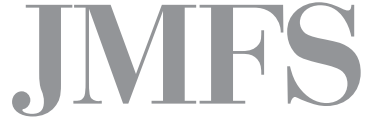

Journal of Management and Financial Sciences
Volume XIII

Issue 41 (June 2020

pp. 9-32

SGH Warsaw School of Economics

Collegium of Management and Finance

Leszek Mosiejko

Collegium of Management and Finance

SGH Warsaw School of Economics

ORCID: 0000-0002-3726-3547

Michał Bernardelli

Institute of Econometrics

Collegium of Economic Analysis

SGH Warsaw School of Economics

ORCID: 0000-0002-5504-257X

\title{
Dynamic measurement of the financial liquidity of Polish companies listed on the Warsaw Stock Exchange between 2002 and 2017: cross-sectoral comparative analysis - Part 2
}

\footnotetext{
AbstRact

The purpose of the present research was to analyse Polish listed companies in terms of liquidity management in 2002-2017 in a dynamic context. Evaluation of the dynamic model of corporate financial liquidity was carried out with the use of classical descriptive statistics tools and methods applied in such analyses. The companies were analysed in the new sectoral layout implemented by the Management Board of the Warsaw Stock Exchange in January 2017. ${ }^{1}$ The study of the dynamic financial liquidity of enterprises on the basis of selected ratios consisted of two parts. In the first part of the study, a series of medians was determined for each of the liquidity ratios in particular sectors. Each element of the series is associated with the quarter from which the data came. The
}

1 Sectoral qualification of the examined companies was implemented in accordance with the regulation introduced by the Management Board of the Warsaw Stock Exchange based on a press release by the Board, dated on December 29, 2016; retrieved from: www.gpw.pl/pub/GPW/STATIC/files/29.12.16kom4.pdf (accessed: 15.10.2018). 
ratios within sectors were then compared so that coexistence of changes over time, shifts in relation to one another, or the lack of clear interdependencies could be observed. Unlike the first part, which covered the relationship between the different ratios within a sector, the second part focuses on cross-sectoral comparative analysis. Descriptive statistics based on quantiles were derived for data covering the entire period under consideration and for all enterprises in the sector. Half of the surveyed listed companies (i.e. all the ratio values between the first and third quartiles), were adopted as the central standard. Numerical values of standards for particular ratios and sectors are presented in a tabular form.

Keywords: financial liquidity, dynamic liquidity ratios, sectoral analysis JEL Classification code: G390

\section{Introduction}

Cross-sectoral comparative analysis of the dynamic measurement of the financial liquidity of companies listed on the Warsaw Stock Exchange between 2002 and 2017 is a continuation of studies into financial liquidity of enterprises that underwent statistical analyses [Mosiejko, Bernardelli, Sierant, 2019]. The present paper aims at conducting a deeper analysis within the frame of shaping financial liquidity.

The notion of financial liquidity of enterprises is presented in the literature in various aspects, depending on the perspective on the subject. Considering the most general understanding of financial liquidity, it means a company's ability to repay its current liabilities [Jerzemowska, 2006, p. 135; Michalski, 2004a, p. 66]. A more detailed definition relates to the financial liquidity of the company with regard to material matters, which can be equated with an ability of a company to convert its assets into cash as soon as possible and without impairment to value [Wędzki, 2002, p. 33]. In this understanding of a company's financial liquidity, cash is the basic means of exchange necessary to complete various economic transactions; it is indispensable in funding the financial liabilities arising from the operation of the business. The ease with which a company is able to obtain additional cash resources by converting other assets into cash constitutes a company's liquidity scale [Kusak, 2004, p. 9].2

A company's financial liquidity may also be understood as its solvency. In this context, it is a possibility of regulating a company's obligations arising from ordinary transactions, unexpected events, or situations that allow for an "occasional purchase of goods" [Bannok, Manser, 1992, p. 159]. Another interpretation of financial liquidity stems from market space, especially that on the financial market. Such liquidity takes shape when a given market is characterised

2 Assets are characterized by varying degrees of liquidity. Short-term securities that can be easily sold in order to recover cash in exchange transactions at a low transaction cost are treated as high liquidity assets. Real estate or specialised machinery and equipment are much more difficult to dispose of and the transactions may also be accompanied by a significant loss of value. Therefore, they are regarded as low liquidity assets. 
by 'freedom' to make large sales or purchase transactions without fear that adequate demand or supply will not be found [Henderson, Maness, p. 95]. Significant linkages exist between the cited conjunctures on the financial liquidity of the company, the graphic illustration of which is shown in Figure 1.

Figure 1. Associations between three forms of financial liquidity

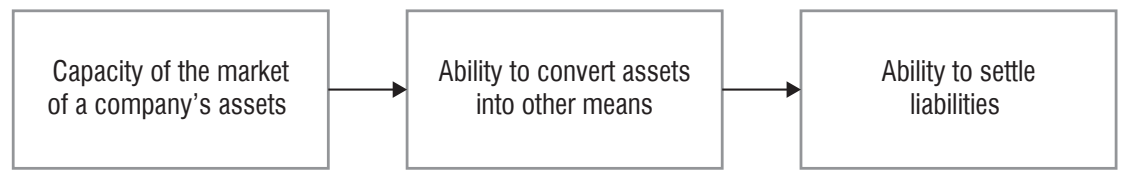

Source: Michalski [2004a], p. 66.

Should a need arise to settle a liability of a size exceeding the resources of the debtor and their equivalents, the possibility of payment will depend on whether there is an opportunity to convert the assets that are held by the debtor into cash [Jerzemowska, 2006, p. 135]. If it proves to be possible, then the liability may be settled in a timely manner. The possibility of such a conversion depends on the 'capacity' of the market of assets held by the debtor. Therefore, the ability to regulate the debtor's liabilities is dependent on the capacity of the market of the assets at the debtor's disposal. The third expression of a company's financial liquidity may also occur when the ability to convert the company's assets into other asset types is low (i.e. as a result of a company holding an unused credit line for an appropriate amount). On the other hand, though, assets that remain available to the company in a bank may be considered as assets at its disposal by means of credit financing [Michalski, 2004a, pp. 66-67].

Assessment of a company's financial liquidity at a given moment in time requires an appropriate, static reasoning for the existing relationship between the various components of the current assets and the financing of short-term liabilities. Analysis of the financial liquidity in this respect is based on the selection of relevant indices, the structure of which is based on the use of the data contained in the company's balance sheet. Despite its numerous limitations, statistical analysis is widely used in order to perform and obtain company assessments. Statistical indicators enable assessment of companies independently from their size, which in turn renders it possible to conduct wide-scale comparative analyses within the frame of monitoring levels of liquidity. However, the static analysis of the financial liquidity of a company based on the use of on-balance sheet data does not take into account the information necessary to assess the actual financial condition in terms of liquidity. This is due to the very nature of the balance sheet, which is intended to demonstrate that the company owns assets and shows sources of their financing. The need to use other elements of the financial statements to assess the financial liquidity of a company is due, inter alia, to the following existing restrictions [Sierpińska, Wędzki, 2002, pp. 62-63]:

- individual assets included in the balance sheet are valued in accordance with the principle of prudent valuation, which may result in underestimating their actual value; 
- current assets are accounted for by historical costs, which generally differ from their market value;

- the balance sheet of the company does not include information relating to the repayment terms of the foreign capital involved, which determines financial liquidity to a great extent;

- the lack of information in the balance sheet about liability items that require repayment in a particular timeframe and in specific amounts, such as payments under a lease agreement, otherwise known as off-balance-sheet liabilities;

- liquidity from the perspective of a balance sheet is determined by the specific moment in time when the balance sheet is drawn up, which affects subjectivity of the size of the balance sheet data, particularly in the case of production seasonality;

- individual balance sheets may be deliberately shaped by managing authorities in order to achieve more favourable financial results for the date of the financial statements, in the form of, say, introducing a restrictive policy for debt collection, optimisation of storage inventory, or extension of obligations.

Considering the above inter alia factors, it is possible to state that due to its static character, a balance sheet does not provide sufficient information to examine a company's financial liquidity, the essence of which is the synchronisation of generated cash flows and expenditure [Kusak, 2004, p. 10]. Construction of static measures based on data from a company's balance sheets does not make it possible to monitor the need for additional cash resulting from the lack of synchronisation between liability payment deadlines and deposits of amounts receivable.

\section{Dynamic corporate financial liquidity: an overview of definitions}

Analysis of dynamic corporate financial liquidity refers to a particular timeframe the data contained in the cash flow statement is used in the summary of actual cash flows for a given period [Nowak, 2014, p. 222; Ostrowska, Niedźwiedzka, 2015, p. 160; Grzywacz, 2015, pp. 43-47]. In order to carry out an in-depth analysis of the financial liquidity of a company, taking into account the actual cash flow, dynamic indices based on future cash flows generated by assets are used [Niemiec, 2014, pp. 57-59; Gołębiowski, Grycuk, Tłaczała, Wiśniewski, 2014, pp. 166-173]. The composition of the company's dynamic liquidity ratios based on cash flows reported in the cash flow statement allows for an analysis of its cash resources, including financial planning, assessment of the effectiveness of current investment projects, company valuation, or bankruptcy forecasting. The use of the dynamic liquidity metrics of a company in the financial analysis makes it possible to determine which areas of its activities generate inflows and outflows as well as their role in the development of generated profit [Wajszczuk, 2013, pp. 114-115]. Jerzemowska defines dynamic liquidity as a flow of financial processes in form of cash revenues and expenditures [Jerzemowska, 2006, p. 136]. According to Krzemińska, a company retains its liquidity when expenditure resulting from current 
short-term liabilities and the necessary future expenditure are covered by the financial resources expected from current cash receipts [Krzemińska, 2002, p. 28]. A slightly different approach to dynamic financial liquidity is presented by Wojciechowska, who defines it as an ability of a company to purchase goods and services of all kinds when they are needed to meet the entity's production needs, as well as its ability to regulate all kinds of financial obligations in full and within the applicable time limits [Wojciechowska, 2001, p. 14]. In this case, determining liquidity includes all necessary expenses, not just those that result from existing obligations. Moreover, the ability to make purchases or regulating obligations is not defined by the size and structure of current assets, but by an overall ability to pay [Wojciechowska, 2001, p. 16]. According to Kusak, this way of understanding corporate financial liquidity is described as liquidity in terms of cash flow [Kusak, 2004, p. 10].

The dynamic understanding of financial liquidity differs significantly from its static understanding [Uyar, 2009]. The current state of the financial assets with a liquidation period of up to one year as well as the state of short-term liabilities with a maturity of up to one year form the basis for determining the financial liquidity by means of a static balance. Both financial categories are known at the moment of determining financial liquidity. However, revenue and expenditure, which will arise in the near future in connection with undertaken economic activity, will not be included. The temporal distribution of the liquidation of current assets and the maturity of short-term liabilities is also ignored. According to the static understanding, it is beneficial to maintain a high state of liquid assets with a high liquidity position.

The dynamic approach to liquidity covers all events and phenomena that generate revenue and expenditure over a given period. Account is, therefore, taken of not only the cash effects that arise from existing assets and liabilities, but also those that will only arise in association with undertaken economic and financial processes. Dynamic measurement of the financial liquidity of a company includes both ex post conceptualisation, based on cash flow data, and ex ante conceptualisation, used in the current liquidity management and in the process of building cash flow forecasts for future periods. In this context, liquidity is primarily determined by the ability to generate revenue rather than existing stock of liquid assets [Kusak, 2004, p. 11]. Figure 2 below presents this relation.

Figure 2. Relation between components of financial liquidity in a company

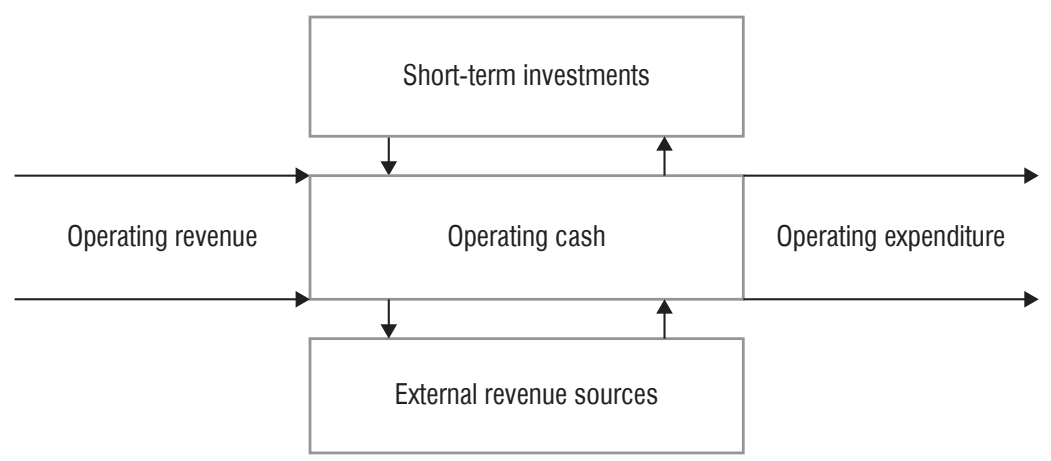


According to Kusak, the ability to maintain financial liquidity refers to the possibility of generating revenue streams exceeding cash flows; it depends on carrying out a particular policy by company management in order to optimise the use of its resources [Kusak, 2004, p. 11].

Business decisions made in the company shape the size of revenue streams and cash expenditure. Limiting expenditure to what is actually possible to pay increasing sales volumes may help maintain financial liquidity. Additionally, more efficient recovery of claims may increase cash inflows to the company. Cash resources that exist in the beginning of a given period are the result of the relationship of revenue to expenditure over the previous periods. High revenues in relation to expenditure for previous periods increase payment capacity in the current period, and conversely, low revenue in relation to expenditure reduces cash resources and payment possibilities in the current period. Cash equivalents (i.e. current assets characterised by very high liquidity) are mainly short-term securities. What characterises them is the possibility of quick conversion into cash without major financial losses. In addition, maintaining them confers additional revenue on the company. Maintaining a certain level in terms of value of the short-term securities is, in addition to cash stocks, an important determinant of the company's financial security. The fact of having them may be considered as an internal liquidity reserve [Michalski, 2004b, p. 16]. The ability to obtain external financing for the day-to-day operation can be defined as an external liquidity reserve. An enterprise that has the possibility of obtaining relevant credit lines or loans quickly can easily cover outstanding commitments or finance emerging expenditure.

It is an important factor for the management of a company to have the cash to secure liquidity and solvency of the company, with a quick turnaround time. Liquidity ratio analysis based on the underlying data from a financial statement makes it possible to assess the size of the cash flows generated by the company, which in the longer term makes it possible to control maturity dates of the liabilities. Moreover, thanks to the ratio analysis, it is possible to identify those areas of activity that generate positive financial flows from its core business, risks arising from timely settlement of commitments, or to conduct industry and inter-sectoral comparative analysis with other companies [Grabowska, 2012, pp. 13-15].

\section{Dynamic measurement of liquidity}

Assessment of the company's liquidity in a dynamic context is mainly based on data derived from its cash flow statement, which allows, inter alia, for assessing sources of differences between the achieved yield and the cash balance, the company's ability to settle liabilities and pay dividends, sources of its cash, as well as cash effects of its investment and financial activities [Bieniasz, Gołaś, 2006, p. 32]. Dynamic liquidity indicators include the operating cash flow/sales ratio and cash flow coverage ratio. The operating cash flow/sales ratios show the existing relationship between the cash flow generated from the company's operating activities and the volume of sales or total assets [Sierpińska, Wędzki, 2007, p. 52]. The higher the value 
of the operating cash flow/sales ratio, the higher the capacity to finance expenditure [Kusak, 2004, p. 56]. The cash flow coverage ratios illustrate the relationship between the company's cash obtained from its fundamental activities and its liabilities. The higher the values the cash flow coverage ratios achieve, the more favourable the company's financial condition becomes [Sierpińska, Wędzki, 2007, p. 53].

In the present paper, two groups of indicators that include the operating cash flow/sales ratio and cash flow coverage ratio were selected for the dynamic assessment of the ability to pay by companies listed on the Warsaw Stock Exchange. The structure of the operating cash flow/sales ratio is based on cash flows resulting from a company's operational activities, while informing about the existing relation between the cash obtained from fundamental activity and the revenue generated from sales, profit, or assets [Gołębiowski, Tłaczała, 2009, p. 221]. The following are examples of the operating cash flow/sales ratios:

\section{Operating cash flow/sales ratio}

$$
C S E=\frac{N C f O A}{N S}
$$

where: $C S E$ - cash sales efficiency, NCfOA - net cash from operating activity NS - net sales.

\section{Operating cash flow/income ratio}

$$
C I E=\frac{N C f O A}{I f O A}
$$

where: $C I E$ - cash income efficiency, NCfOA - net cash from operating activity IfOA - income from operating activity.

Operating cash flow/assets ratio (equity and foreign capital invested)

$$
C A E=\frac{N C f O A}{M V o O A}
$$

where: $C A E-$ cash asset efficiency, $N C f O A$ - net cash from operating activity $M V o O A$ - mean value of overall assets

Operating cash flow/sales ratios make it possible to assess cash flow efficiency of a company. The operating cash flow/sales ratio shows the relation between the cash generated from operating activities and the sales volume. In other words, what percentage of the margin is cashed [Gołębiowski, Tłaczała, 2009, p. 222]. ${ }^{3}$ The operating cash flow/income ratio is known as a measure of cash quality of financial results; if it is calculated based on the income from

3 Income is registered in its net amount - excluding the VAT tax, whereas flows from operating activities usually include all taxes, both paid and payable. 
sales, it informs what percentage of income comes in a form of cash. The operating cash flow/ assets ratio determines the potential of a company's assets to generate cash and is also known as assets' cash productivity [Gołębiowski, Tłaczała, 2009, p. 222, after: Maślanka, 2008, p. 66].

The structure of cash flow coverage ratios is used to assess the ability of a company to generate cash from its operating activities to cover expenditure on investment in fixed assets, repayment of liabilities, as well as payments on dividends [Gołębiowski, Grycuk, Tłaczała, Wiśniewski, 2014, p. 206]. The following are some examples of ratios that fall in this category: ${ }^{4}$

\section{Cash flow coverage ratio for repayment of debt in general}

$$
G C F f R o D i G=\frac{N C f O A}{T L}
$$

where: GCFfRoDiG - general cash flow coverage for repayment of debt in general, NCfOA - net cash from operating activity, $T L$ - total liabilities.

Operating cash flow coverage ratio for the purchase of fixed assets

$$
\text { OCFfPoFA }=\frac{N C f O A}{E o F A}
$$

where: OCFfPoFA - operating cash flow coverage for the purchase of fixed assets, NCfOA - net cash from operating activity, EoFA - expenditure on fixed assets.

The cash flow coverage ratio for repayment of debt in general provides information about a company's capabilities for repaying its liabilities with financial resources generated by means of its operating activities. The operating cash flow coverage ratio for the purchase of fixed assets provides information about the percentage of cash generated from a company's operating activity devoted to investment.

\section{Data characteristics}

The study was based on quarterly data about companies listed on the Warsaw Stock Exchange. The data was rendered available by the Notoria Serwis SA Company and covered the period of the third quarter 2002 to the end of the fiscal year 2017 for 389 companies. The number of companies and the timeframe per quarter allowed for the analysis of 9,148 records. Seven sectors of the economy were selected for analyses. ${ }^{5}$ Each company was ascribed to one and only one sector listed in Table 1 below.

4 The domain of cash flow coverage is characterised by many indicators, yet for the needs of the current study, we focus on the cash flow coverage ratio for repayment of debt in general as well as the operating cash flow coverage ratio for the purchase of fixed assets.

5 Sectoral classification of listed companies includes eight sectors. The financial sector is the eighth, but it was not included in this study due to the specificity of its operations. 
Table 1. Number of companies under analysis per sector of the economy

\begin{tabular}{|l|c|}
\hline \multicolumn{1}{|c|}{ Sector } & No. of companies \\
\hline oil and energy & 21 \\
\hline chemicals and raw materials & 43 \\
\hline industrial, construction and assembly production & 124 \\
\hline consumer goods & 57 \\
\hline retail and service & 76 \\
\hline healthcare & 19 \\
\hline technologies & 49 \\
\hline
\end{tabular}

Source: own classification based on company accounts.

Only those companies in the case of which all five analysed liquidity ratios treaded in positive territories were included in the analysis. Table 1 above shows the numbers of those companies per individual sectors.

The goal of the study, whose results are described in the present paper, was to perform intra- and inter-sectoral analysis. To this end, quantile measures were applied, with a particular focus on the second quartile of observations in the examined data sets. An advantage of using a median as opposed to the popular arithmetic mean lies in the fact that the former is relatively resistant to outlier observations. From the vantage point of practical application, addressing similarities between companies in a given sector or finding dominating values are the factors that are of more interest here. Consequently, the paper focuses on showing norms for each ratio, while providing cursory commentary on data outlying the numerical ranges or on situations that could be considered untypical.

\section{Empirical analysis}

The study of corporate financial liquidity with the use of the selected ratios was made up of two parts. Part One identified a series of medians for each liquidity ratio for each sector individually. Each element in the series is associated with a data reporting quarter. Then, comparisons across ratios were conducted within a given sector. Co-occurrence of changes in time, shifts with respect to one another, or the lack of any interdependencies may be observed in graphs for each sector, illustrated in Figures 3-9 below.

As opposed to the first part of the study, which focused on relations between indices per sector, Part Two was devoted to cross-sectoral comparative analysis. Descriptive statistics based on quantiles were identified for all data for the entire examined period and all for companies in a given sector. Median half of the examined companies listed on the Warsaw Stock Exchange was determined as the norm (i.e. all ratio values that fell between the first and third quartile). Figures 10-14 visualise distributions of values in a form of box charts, while 
outlier observations were disregarded. Numerical values of the norms for individual ratios and sectors were collected in Tables 2-6.

In the case of the oil and energy sector (Fig. 3), values of the operating cash flow coverage ratio for purchasing fixed assets as well as the operating cash flow/income ratio clearly stand out from the remaining ratios. However, it is difficult to ascertain that numerical series are characterised by a high degree of similarity [Bernardelli, 2018, pp. 7-20]. ${ }^{6}$ However, it is indeed possible to ascertain that the course of the remaining three ratios are relatively stable in a sense of limited amplitudes in comparison with relative changes in the two ratios mentioned above. Additionally, we can see periods of concurrency (e.g. increases up to approximately 2004, an increase and decrease in 2008-2009) in the case of three ratios: the operating cash flow/sales ratio, operating cash flow/assets ratio, as well as cash flow coverage ratio for repayment of debt in general. In 2017, most ratios dropped or remained at a similar level as in 2016, but in comparison with the values from previous years, it is possible to consider the final year very stable.

Figure 3. Comparison of corporate financial liquidity ratios in the oil and energy sector between 2002 and 2017

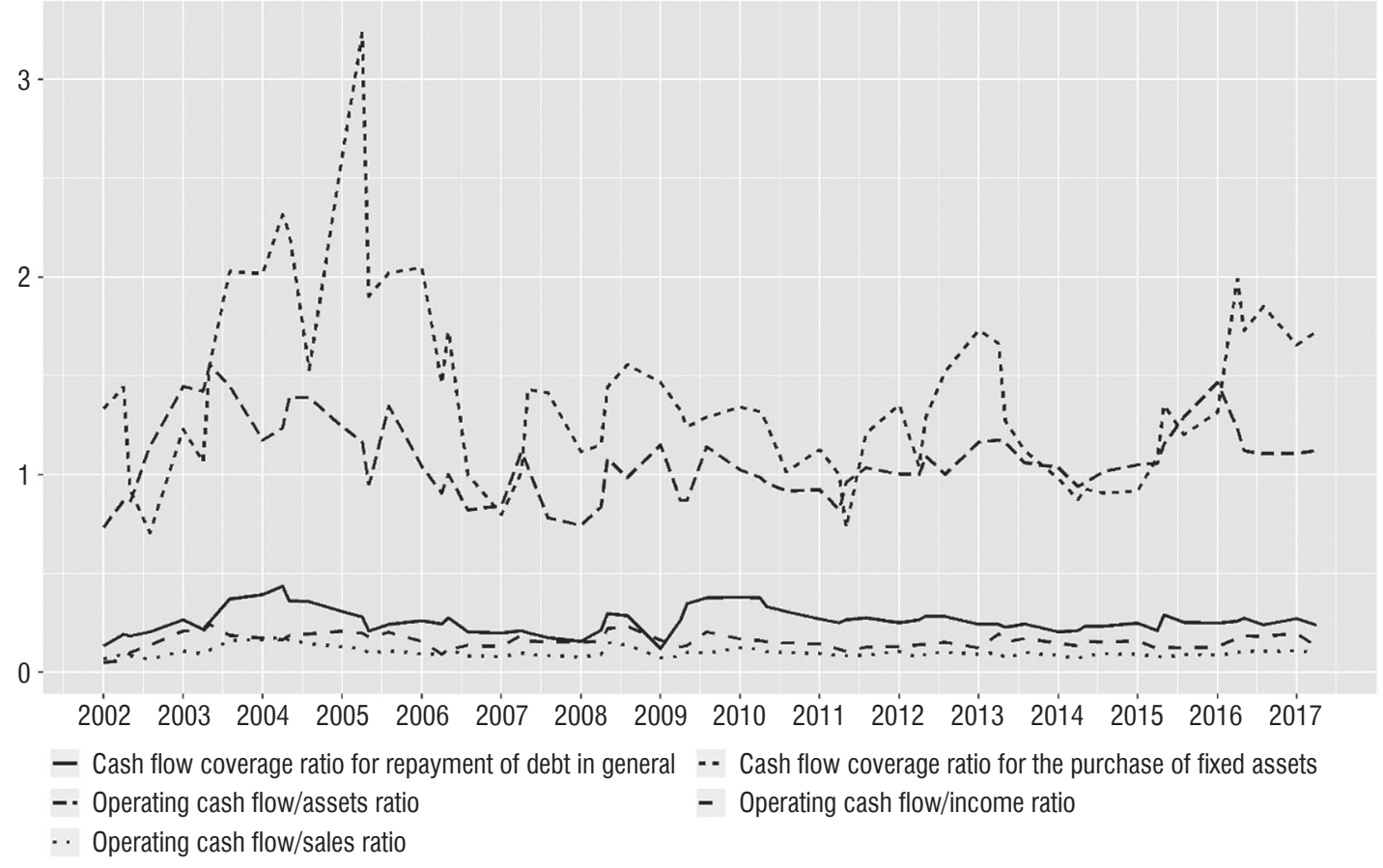

Source: own classification based on company accounts.

The sectors of chemicals and raw materials (Fig. 4), industrial, construction and assembly production (Fig. 5), as well as consumer goods (Fig. 6) are similar in their characteristics based

6 There are many ways of examining similarities across time series, such as co-integration of use of Hidden Markow Models, etc. 
on median values in time to the oil and energy sector. Most of all, values of the operating cash flow coverage ratio for the purchase of fixed assets throughout most of the examined period exceed the values of the remaining ratios. Amplitudes of the fluctuations of this ratio are also clearly the highest, and in many cases, they do not coincide with the direction of the evolution of other indicators. When it comes to the actual value, the second ratio is that of the operating cash flow/income ratio. With a few exceptions, it assumes lower values than the ratio of operating cash flow coverage for the purchase of fixed assets, but its value is significantly greater from the remaining three ratios. In many quarters, it is possible to observe similar 'behaviour' to ratios characterised by lower values, most certainly to a greater extent than in the case of the operating cash flow coverage ratio for the purchase of fixed assets. From the perspective of values, the next ratio is one of the cash flow coverage ratio repayment of debt in general. The remaining two ratios (operating cash flow/sales ratio and operating cash flow/assets ratio) assume similar values, and depending on the period of time, one or the other may be greater. Amplitudes of the fluctuations of the three above-mentioned ratios are diametrically different from fluctuations of the two ratios listed in the beginning. From a global viewpoint, they may be considered stable over time, yet when moving on to relative measures, each ratio undergoes evident changes every quarter, however, in the three sectors in question these changes tend to occur in similar timeframes in the case of the operating cash flow/sales ratio, operating cash flow/assets ratio, as well as cash flow coverage ratio for repayment of debt in general.

\section{Figure 4. Comparison of corporate financial liquidity ratios in the chemicals and raw materials sector between 2002 and 2017}

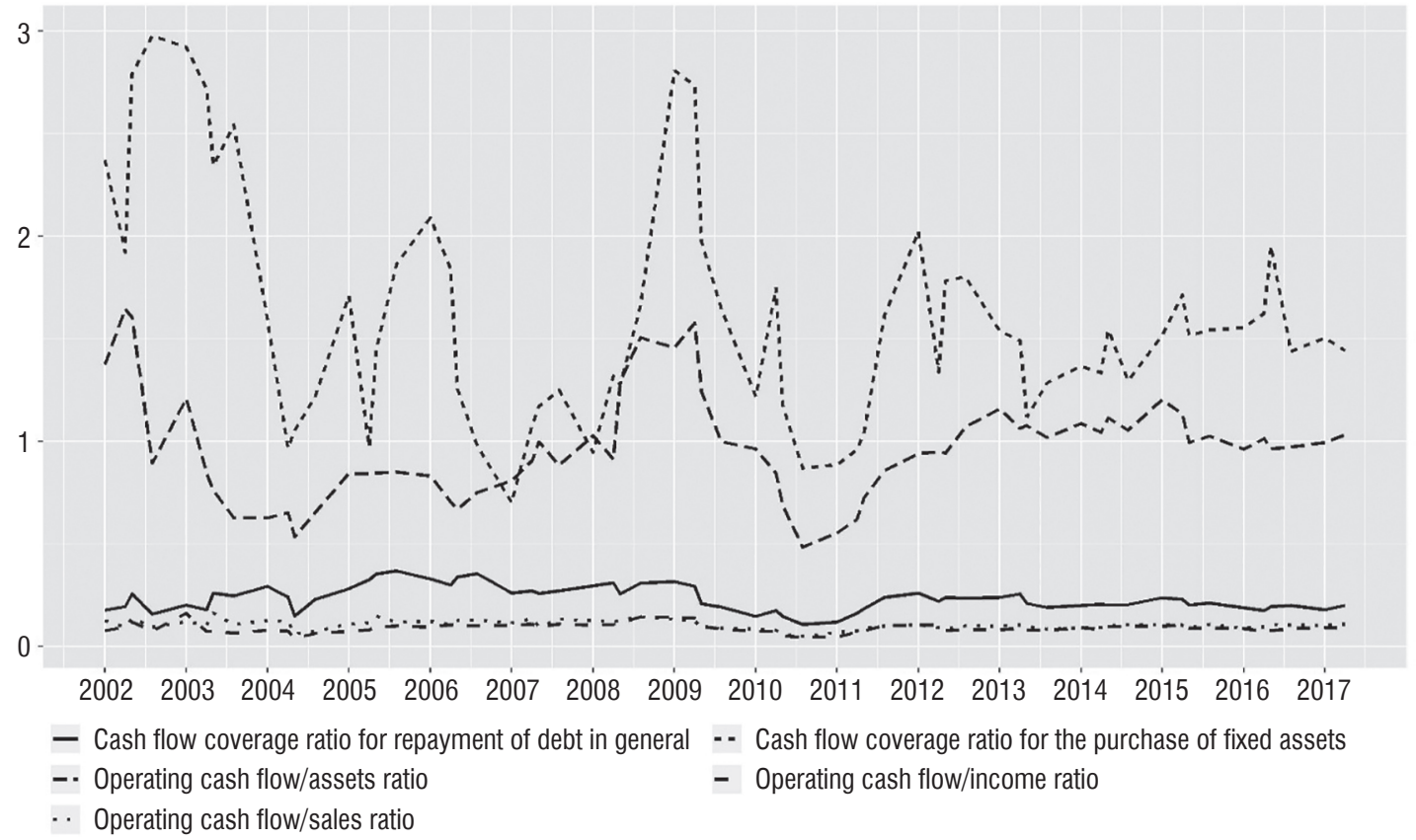

Source: own classification based on company accounts. 
Figure 5. Comparison of corporate financial liquidity ratios in the industrial, construction and assembly production sector between 2002 and 2017

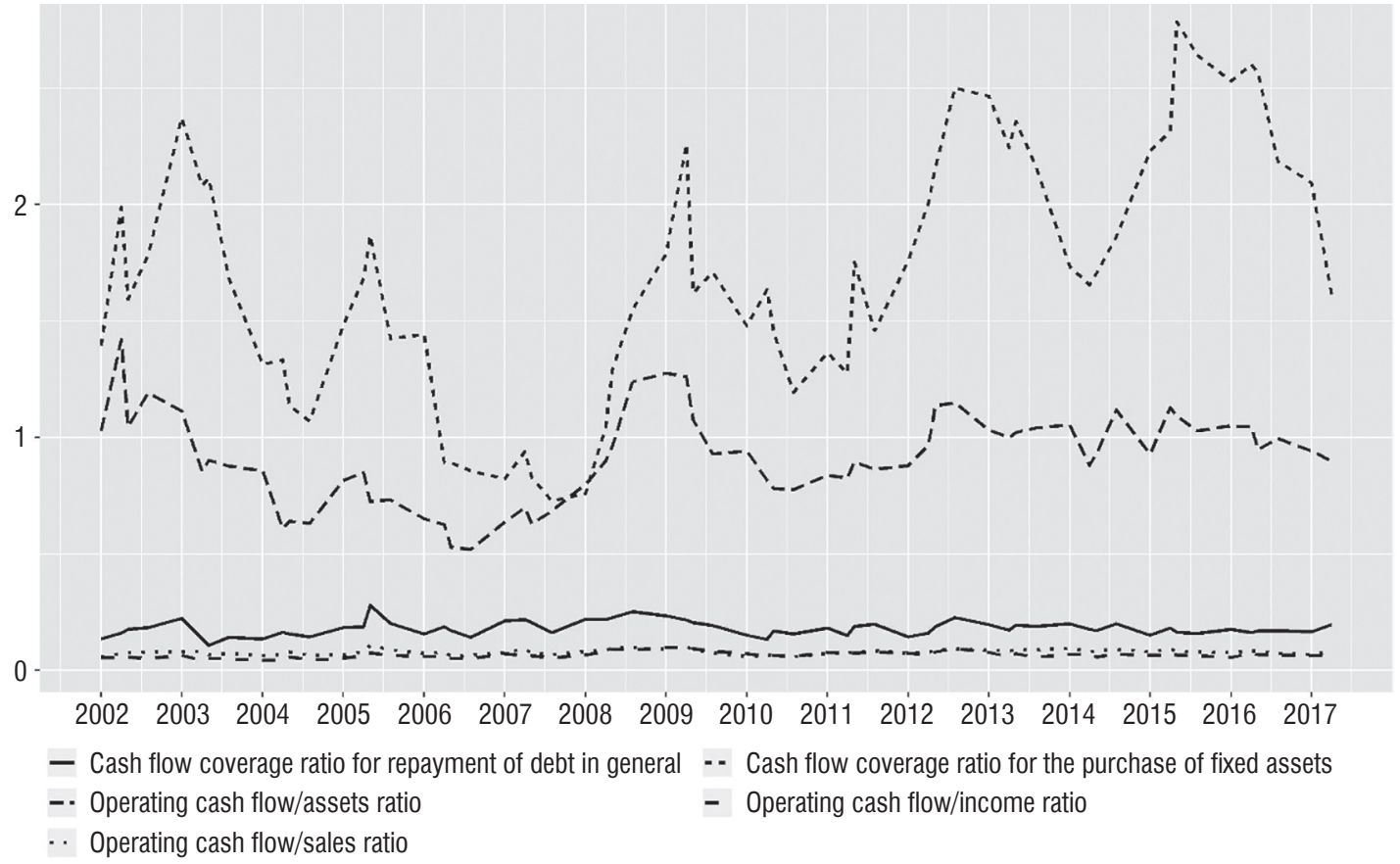

Source: own classification based on company accounts.

\section{Figure 6. Comparison of corporate financial liquidity ratios in the consumer goods sector} between 2002 and 2017

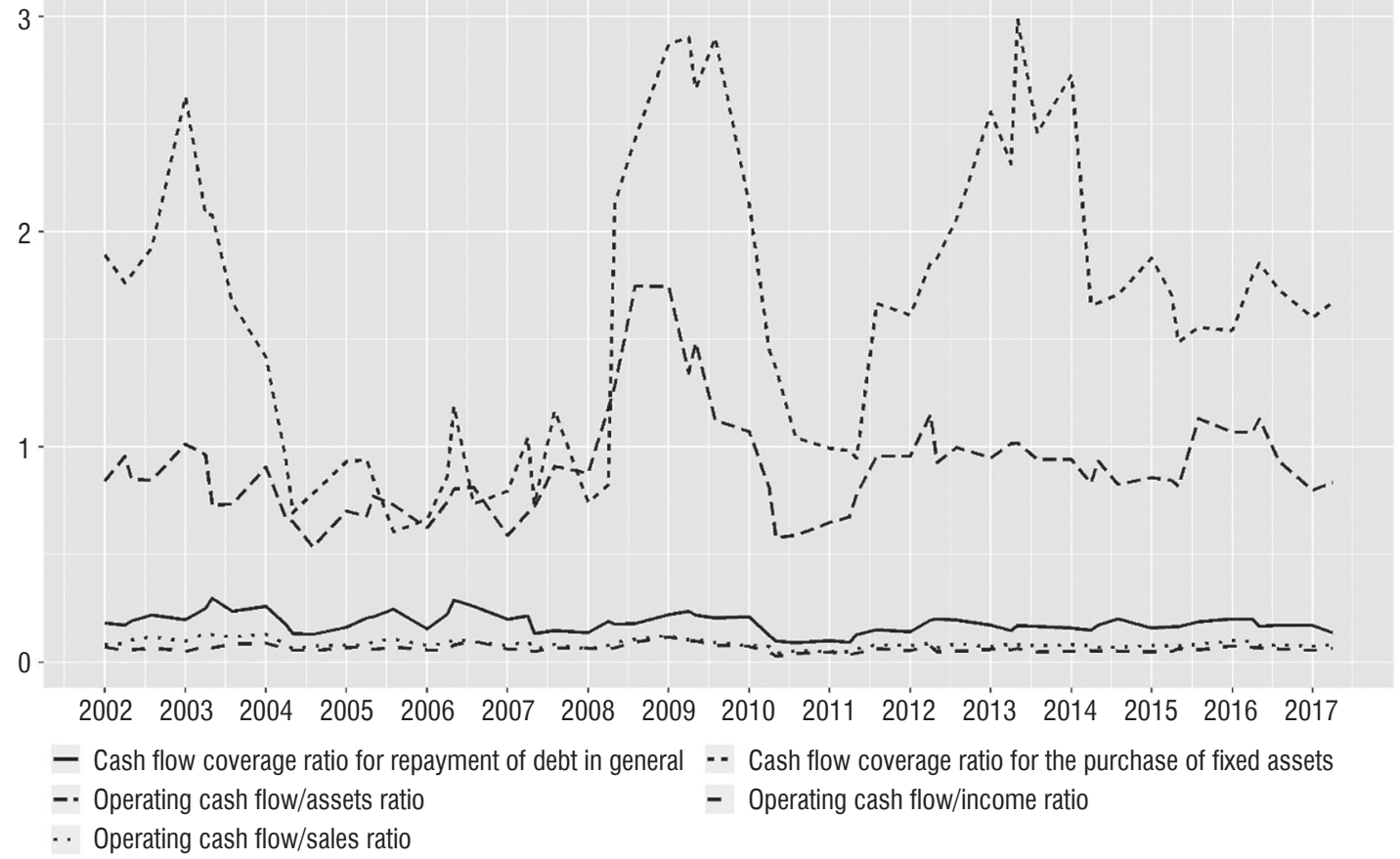

Source: own classification based on company accounts. 
As mentioned, in some periods (e.g. years 2008-2010), the operating cash flow/income ratio underwent a similar pattern of changes. Recognising behaviour patterns as well as conditions for the concurrence of time series requires a deeper analysis.

Indicators for the retail and service sector (Fig. 7) are of a different character from the previously described sectors of the economy, especially in the beginning of the $21^{\text {st }}$ century. Primarily, values of the operating cash flow coverage ratio for the purchase of fixed assets are oftentimes lower than the values of the operating cash flow/income ratio, whereas values of both of these ratios are relatively slightly greater than the values of the remaining three ratios. Later years note a clear increase in the value of the first two ratios with a relative stabilisation of the remaining ratios under discussion. Secondly, there is a lack of a clear correlation between the examined time series. In the case of other sectors, it is possible to identify periods during which time series behave evidently similarly. For the retail and service sector, there are no unquestionable relations that could be brought down to a pattern. Finally, the ratios analysed so far for the sectors revolved around values that could be considered mean. However, in the case of the retail and service sector, some of the ratios could be attached to a long-term trend. Verification of this hypothesis would require a more advanced econometric analysis.

\section{Figure 7. Comparison of corporate financial liquidity ratios in the retail and service sector between 2002 and 2017}

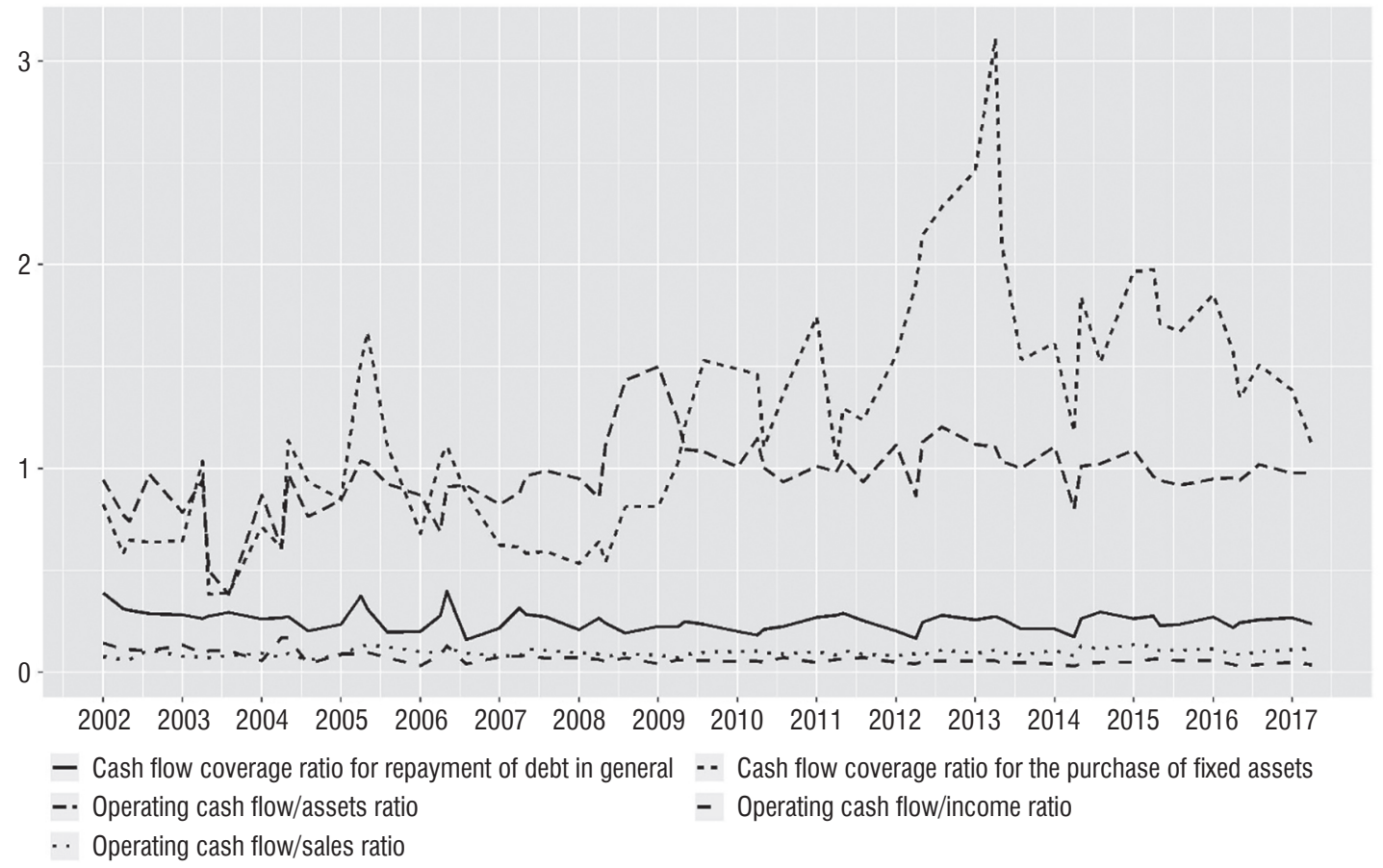

Source: own classification based on company accounts. 
The healthcare sector (Fig. 8) has its own, specific characteristics. Most of all, the range of the presented data for this sector begins in 2010 rather than in 2002, which is the case for all other sectors. This is caused by a very low representation in this sector prior to 2010, which influences not just the untypical and high fluctuations in ratio values, but also does not provide an opportunity to generalise. These fluctuations may be observed in later years, whereas in the last decade the variability of the analysed ratios is significantly limited. The leading ratio is that of operating cash flow/sales, which practically stabilised on a single level at the very outset. It contrasts with drastic changes observed in the values of the operating cash flow coverage ratio for the purchase of fixed assets. Numerical values of all the ratios that may be considered normative are presented in a sectoral distribution in Tables 2-6 and in a figurative way in Figures 10-14.

Figure 8. Comparison of corporate financial liquidity ratios in the healthcare sector between 2002 and 2017

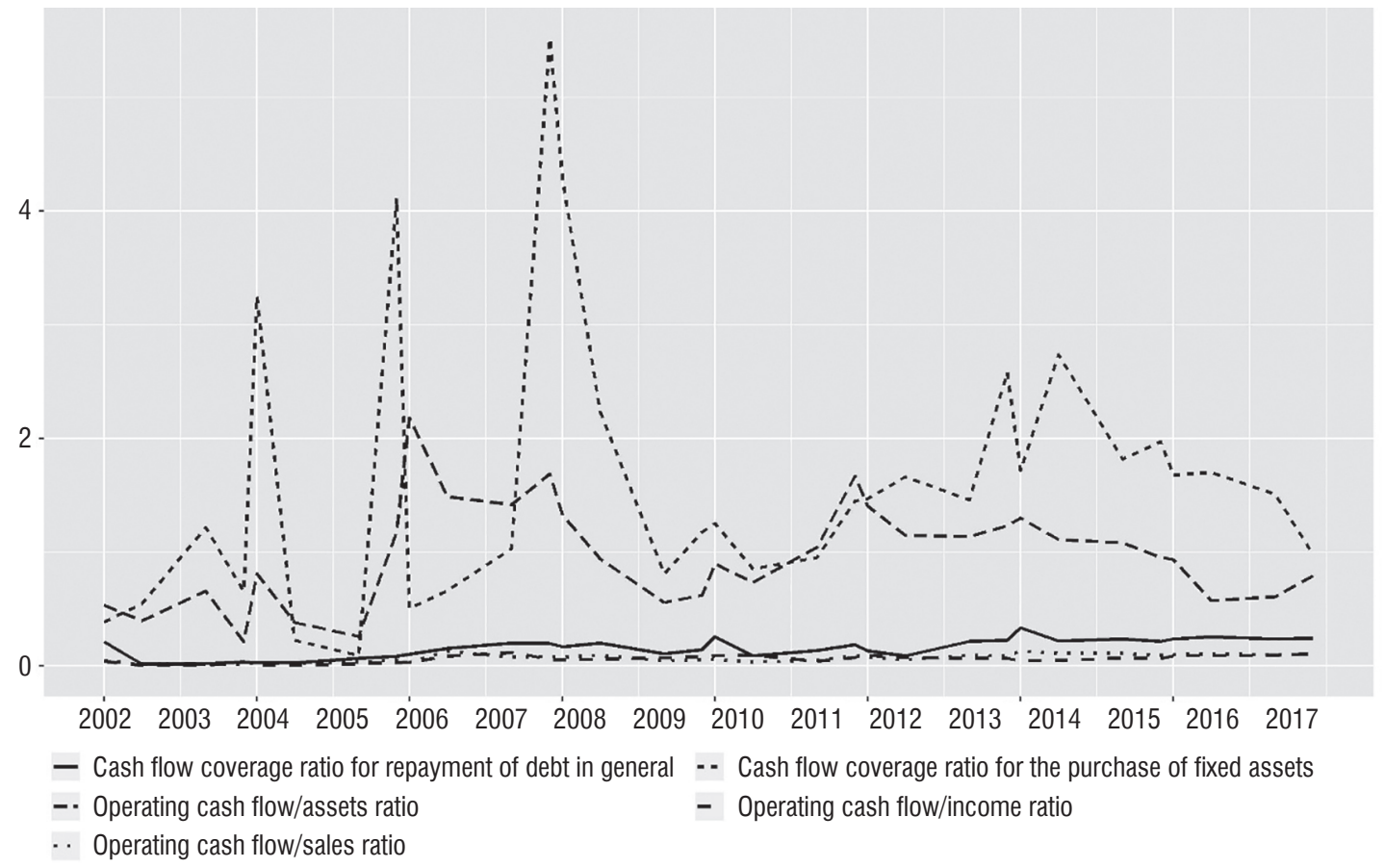

Source: own classification based on company accounts.

The final analysed sector - that of technologies - is similar in many respects to the oil and energy (Fig. 3), chemicals and raw materials (Fig. 4), industrial, construction and assembly production (Fig. 5), as well as consumer goods (Fig. 6) sectors. Relations between individual ratios are clear - the operating cash flow coverage ratio for the purchase of fixed assets is characterised by the highest values, followed by the operating cash flow/income ratio and the cash flow coverage ratio for repayment of debt in general. The remaining two ratios revolve slightly above zero in their values (see Tables 2 and 4). However, it is worth noting the lack 
of clear correlations in the behaviour of individual ratios. It is true that we are able to note an increase in the value of the ratios in 2006 (with the exception of the operating cash flow/ income ratio), or slight peaking in 2012 and 2015, or even a simultaneous increase in the final quarters of 2017, yet it is difficult to ascertain that there is a clear similarity between or among any of the pairs of the compared ratios. In other sectors, the similarities seemed to have been more pronounced.

Figure 9. Comparison of corporate financial liquidity ratios in the technologies sector between 2002 and 2017

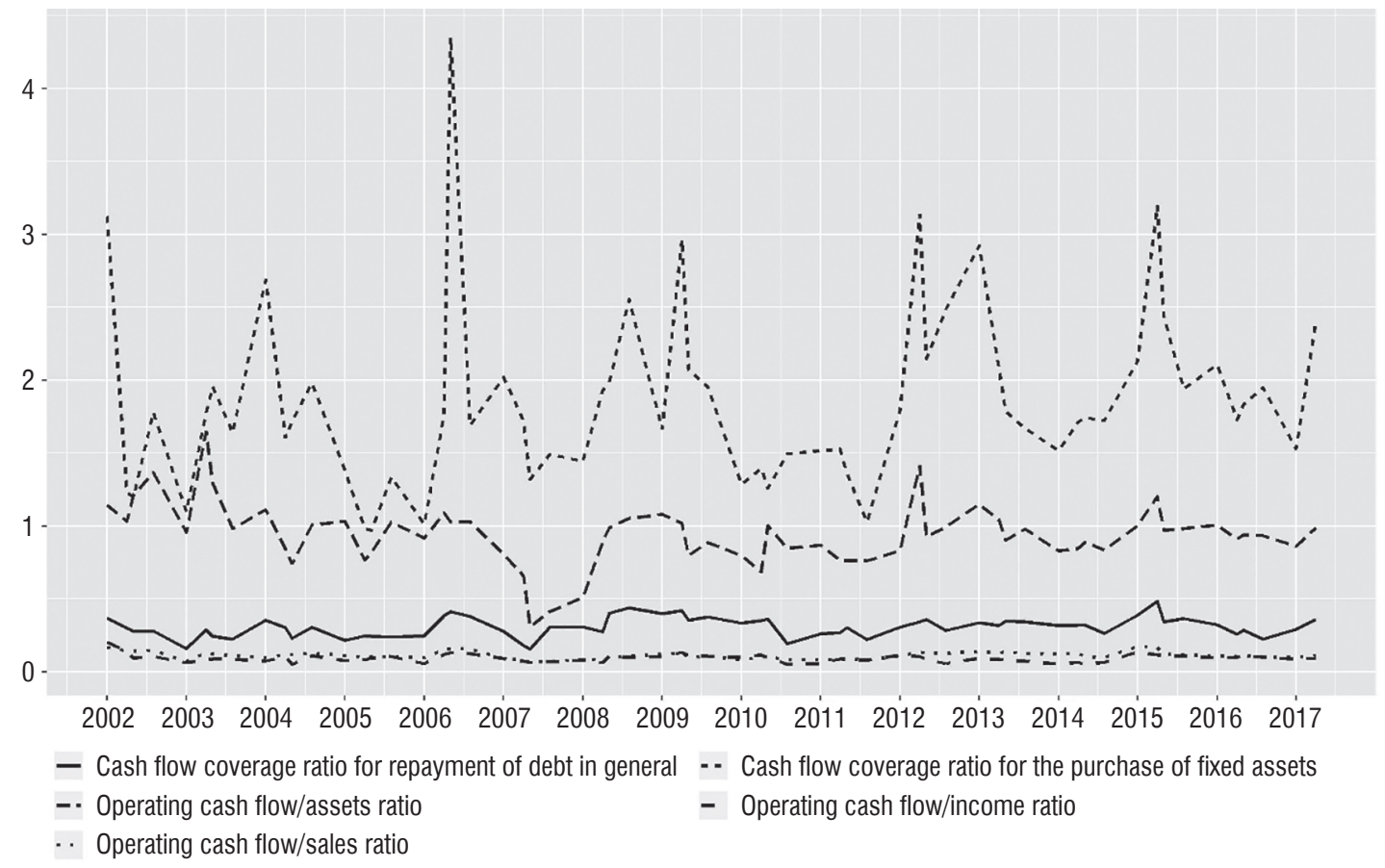

Source: own classification based on company accounts.

Part One of the analysis was limited to comparing each of the fluidity ratios over time separately and independently from each of the seven sectors. A full set of these dynamic ratios, in comparison with static indices, paints an approximate picture of a company's financial situation for the period of 2002-2017. However, in order to determine when we can confidently speak of a company's financial liquidity, versus when its financial condition is somewhat threatened, it is necessary to determine some values which can be considered normative. These norms are dependent on the sector and they must be determined separately for each ratio. Obviously, some ratios may be less conclusive than others, but in some situations, observing them may signal danger for the company some time in advance. Part Two of the study was precisely devoted to examining how the ratios behave in a given sector and to identify numerical ranges that would be applicable to most companies. More precisely, arithmetic means were identified for the liquidity ratios of each company and then classical 
descriptive statistics measures were applied to them. Tables 2-6 provide numerical ranges rounded to three decimal places for $50 \%$ of all the companies for which the calculated ratios fell in the middle range of all values. These ranges may be considered proposals for norms. Exceeding the range significantly in any direction should be considered as a situation that is not necessarily worrying, but clearly departing from a standard for the overall population of companies in a given sector. Additionally, the tables provide arithmetic means for the medians (rounded to two decimal places) as well as noted minimal and maximal values. The collected results of the calculations were obtained after removing outlier values (if any).

In order to visualise better cross-sectoral differences for the values from Tables 2-6, we present them in a form of box charts ${ }^{7}$ (Figures 10-14). Each rectangle in the chart visualises norms from the tables, while the vertical line inside the rectangle shows a mean, and the ends of the so-called whiskers reveal minimal and maximal values.

\section{Figure 10. Comparison of the value of the operating cash flow/sales ratio in the seven sectors under consideration between 2002 and 2017}

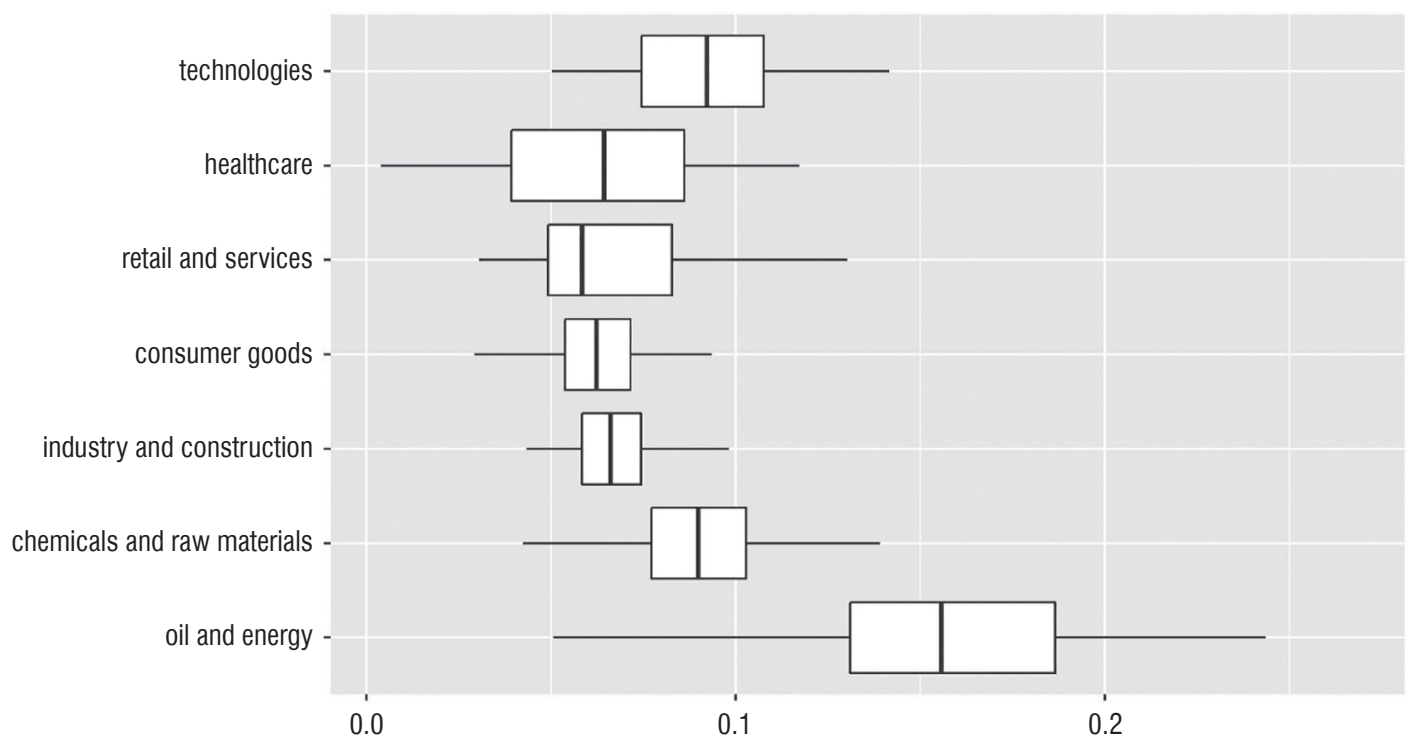

Source: own classification based on company accounts.

Table 2. Comparison of descriptive statistics of the operating cash flow/sales ratio in the seven sectors under consideration between 2002 and 2017

\begin{tabular}{|l|c|c|c|}
\hline \multicolumn{1}{|c|}{ Sector } & Norm (50\% companies) & Mean & Range (min - max) \\
\hline technologies & $0.074-0.108$ & 0.09 & $0.050-0.142$ \\
\hline healthcare & $0.039-0.086$ & 0.06 & $0.004-0.117$ \\
\hline retail and services & $0.049-0.084$ & 0.06 & $0.031-0.134$ \\
\hline
\end{tabular}

7 Excluding outlier values. 


\begin{tabular}{|l|c|c|c|}
\hline \multicolumn{1}{|c|}{ Sector } & Norm (50\% companies) & Mean & Range (min - max) \\
\hline consumer goods & $0.054-0.072$ & 0.06 & $0.029-0.094$ \\
\hline industry and construction & $0.058-0.075$ & 0.07 & $0.043-0.098$ \\
\hline chemicals and raw materials & $0.077-0.103$ & 0.09 & $0.042-0.139$ \\
\hline oil and energy & $0.131-0.187$ & 0.16 & $0.051-0.243$ \\
\hline
\end{tabular}

Source: own classification based on company accounts.

Basing on the box charts for the operating cash flow/sales ratio (Fig. 10) as well as numerical values (Table 2), it is possible to draw at least two conclusions. Firstly, the proposed ranges of norms are characterised by various length depending on the sector. The narrowest ranges refer to the sector of consumer goods, industry and construction, as well as chemicals and raw materials. The longest is the range for oil and energy. The second conclusion refers to norms themselves. In an average company, values that are normative for the oil and energy sector would significantly exceed standards for this ratio in the case of other sectors. The proposed norms for this sector start at 0.13 , while ending at 0.11 for other sectors.

\section{Figure 11. Comparison of the value of the operating cash flow/income ratio in the seven} sectors under consideration between 2002 and 2017

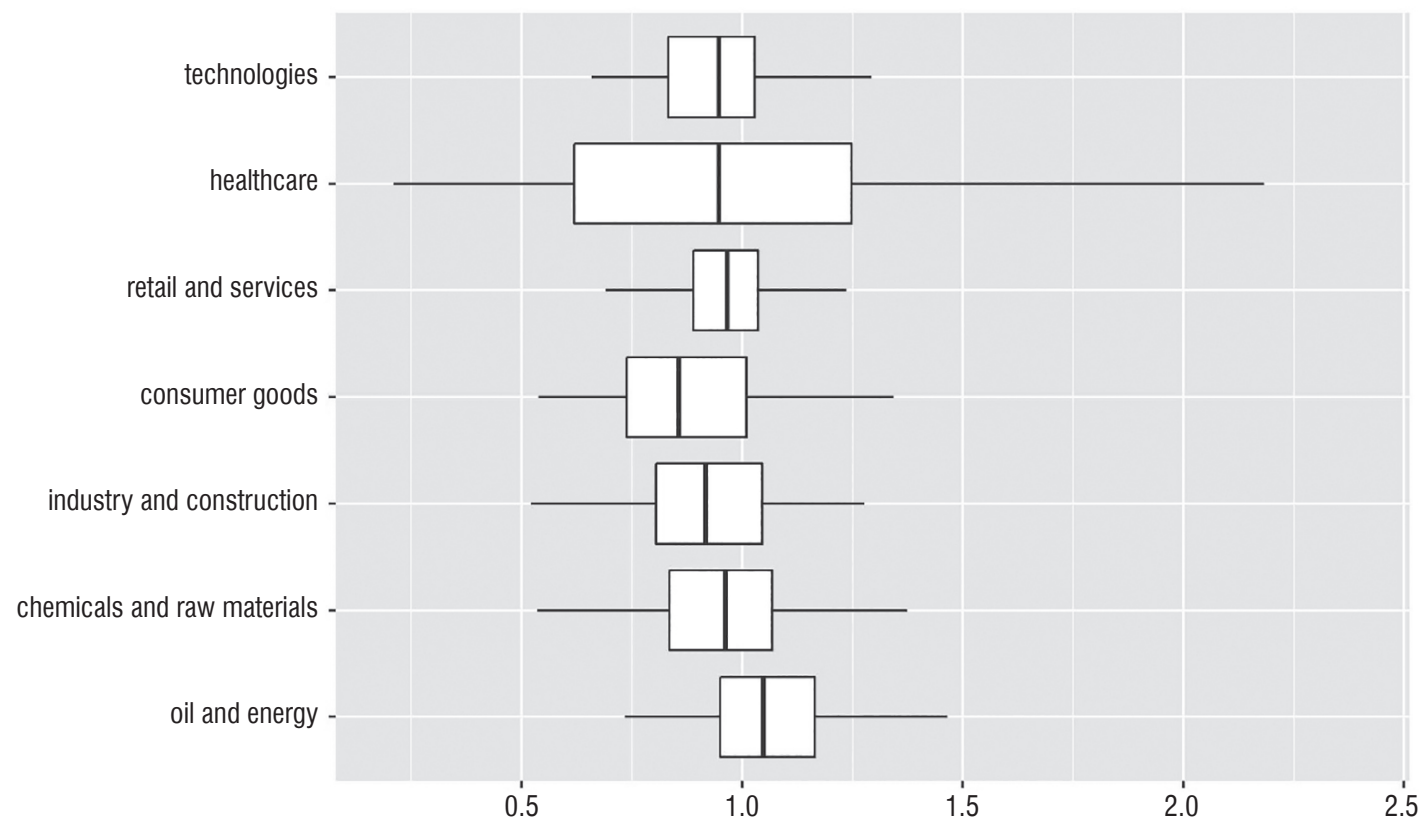

Source: own classification based on company accounts.

Means for the operating cash flow/income ratio (Fig. 11, Table 3) are very similar independently from the sector and revolve between 0.86 and 1.09. However, range lengths differ, with the retail and services sector being the narrowest $(0.88-1.04)$. On the other hand, the largest distances between the first and third quartiles are noted in the healthcare sector 
$(0.62-1.27)$. Diversity in the healthcare sector is not only seen based on the proposed norms, but also by means of the interquartile data range, where the minimal value is at 0.21 and the maximal one is at as much as 2.18. In the case of all the remaining sectors, all the observed values fall between the range of 0.48 and 1.47 .

Table 3. Comparison of descriptive statistics of the operating cash flow/income ratio in the seven sectors under consideration between 2002 and 2017

\begin{tabular}{|l|c|c|c|}
\hline \multicolumn{1}{|c|}{ Sector } & Norm (50\% companies) & Mean & Range (min - max) \\
\hline technologies & $0.832-1.029$ & 0.95 & $0.659-1.293$ \\
\hline healthcare & $0.615-1.265$ & 0.95 & $0.210-2.183$ \\
\hline retail and services & $0.881-1.037$ & 0.97 & $0.691-1.237$ \\
\hline consumer goods & $0.735-1.013$ & 0.86 & $0.538-1.343$ \\
\hline industry and construction & $0.800-1.047$ & 0.92 & $0.521-1.277$ \\
\hline chemicals and raw materials & $0.833-1.069$ & 0.96 & $0.484-1.373$ \\
\hline oil and energy & $0.948-1.165$ & 1.05 & $0.734-1.466$ \\
\hline
\end{tabular}

Source: own classification based on company accounts.

Figure 12. Comparison of the value of the operating cash flow/assets ratio in the seven sectors under consideration between 2002 and 2017
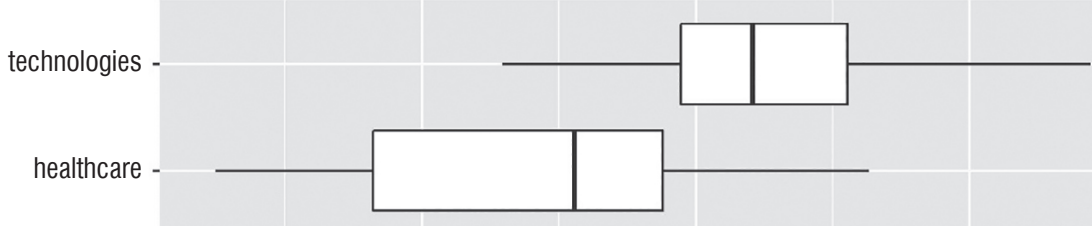

retail and services .

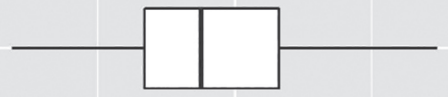

consumer goods -

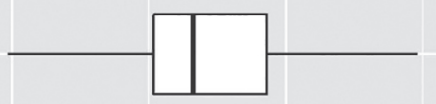

industry and construction .

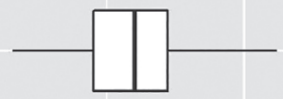

chemicals and raw materials .

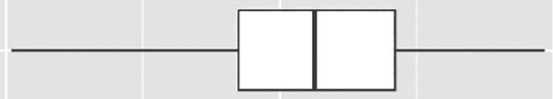

oil and energy

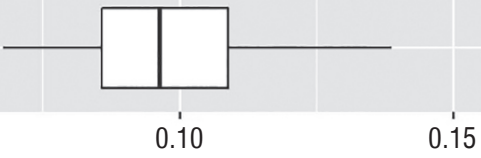

Source: own classification based on company accounts.

In contrast to the operating cash flow/income ratio, mean values of the operating cash flow/assets ratio are significantly different in individual sectors (see Fig. 12 and Table 4). When it comes to the length of ranges for the proposed norms, they are relatively short, with the 
exception of the healthcare sector, whose norm $(0.04-0.10)$ is a few times wider than is the case of the remaining sectors. Additionally, we noted that the values of the ratio for this sector are generally smaller than in other sectors. Comparatively, a mean for the healthcare sector is at 0.08 , which is where we begin the proposed norms. Only in the industry and construction sector, the range starts at 0.07 . Whereas the lowest values are indeed noted for the healthcare sector, it is relatively largest for the technologies sector. The top range for this norm is at 0.13 , but the highest values we noted reach as much as 0.17 .

Table 4. Comparison of descriptive statistics of the operating cash flow/assets ratio in the seven sectors under consideration between 2002 and 2017

\begin{tabular}{|l|c|c|c|}
\hline \multicolumn{1}{|c|}{ Sector } & Norm (50\% companies) & Mean & Range (min - max) \\
\hline technologies & $0.097-0.128$ & 0.11 & $0.065-0.172$ \\
\hline healthcare & $0.038-0.095$ & 0.08 & $0.012-0.132$ \\
\hline retail and services & $0.083-0.108$ & 0.09 & $0.059-0.137$ \\
\hline consumer goods & $0.076-0.097$ & 0.08 & $0.049-0.129$ \\
\hline industry and construction & $0.072-0.086$ & 0.08 & $0.058-0.106$ \\
\hline chemicals and raw materials & $0.092-0.121$ & 0.11 & $0.051-0.148$ \\
\hline oil and energy & $0.086-0.109$ & 0.10 & $0.068-0.139$ \\
\hline
\end{tabular}

Source: own classification based on company accounts.

Figure 13. Comparison of the value of the cash flow coverage ratio for repayment of debt in general in the seven sectors under consideration between 2002 and 2017

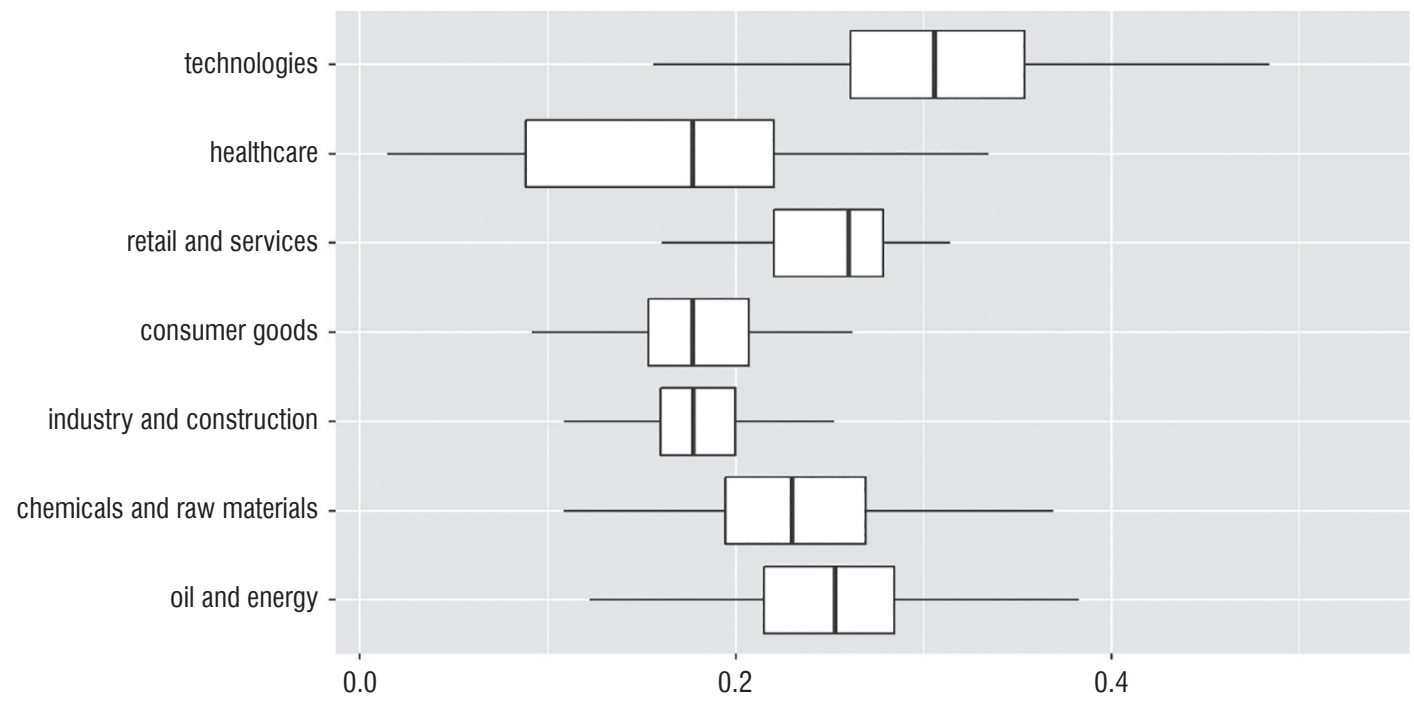

Source: own classification based on company accounts.

Observations of the cash flow coverage ratio for repayment of debt in general (Fig. 13, Table 5) are analogous to those presented in the case of the operating cash flow/assets ratio. Mean values are diametrically different across sectors. Obviously, the numerical values 
themselves are different (higher) than in the case of the ratio described in the previous paragraph, but relative relations across sectors are quite similar. Especially the range of norms for the healthcare sector $(0.09-0.22$; mean 0.18$)$ are clearly lower than in the remaining six sectors. However, the largest values are noted in the technologies sector $(0.26-0.35$; mean 0.31$)$.

Table 5. Comparison of descriptive statistics of the cash flow coverage ratio for repayment of debt in general in the seven sectors under consideration between 2002 and 2017

\begin{tabular}{|l|c|c|c|}
\hline \multicolumn{1}{|c|}{ Sector } & Norm (50\% companies) & Mean & Range (min - max) \\
\hline technologies & $0.260-0.354$ & 0.31 & $0.156-0.484$ \\
\hline healthcare & $0.088-0.223$ & 0.18 & $0.015-0.335$ \\
\hline retail and services & $0.220-0.279$ & 0.26 & $0.161-0.314$ \\
\hline consumer goods & $0.152-0.207$ & 0.18 & $0.092-0.262$ \\
\hline industry and construction & $0.159-0.200$ & 0.18 & $0.109-0.253$ \\
\hline chemicals and raw materials & $0.194-0.272$ & 0.23 & $0.108-0.369$ \\
\hline oil and energy & $0.214-0.285$ & 0.25 & $0.122-0.383$ \\
\hline
\end{tabular}

Source: own classification based on company accounts.

Figure 14. Comparison of the value of operating cash flow coverage ratio for the purchase of fixed assets in the seven sectors under consideration between 2002 and 2017

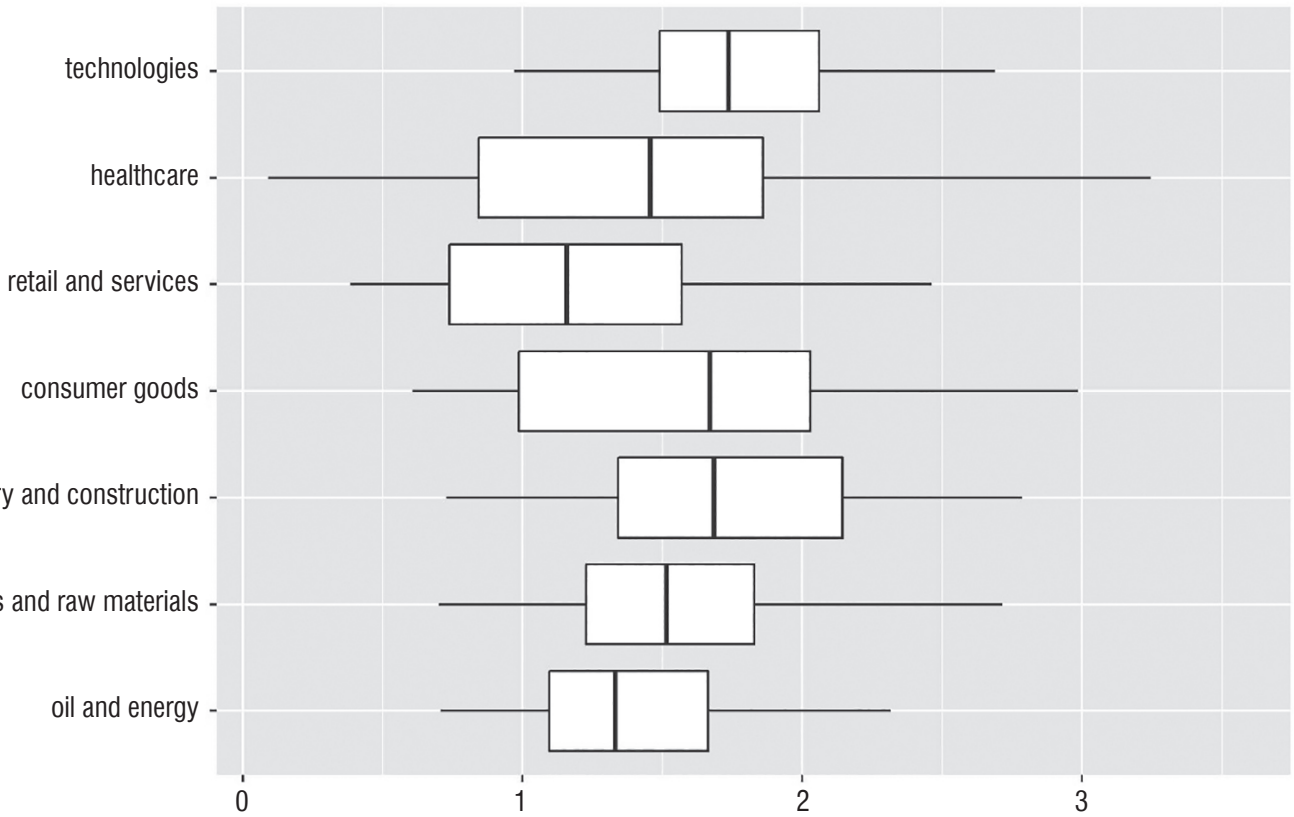

Source: own classification based on company accounts.

The last ratio under consideration (operating cash flow coverage ratio for the purchase of fixed assets), assumes values larger by several orders of magnitude than those for the remaining four ratios. However, the means themselves are similar in size independently 
from the sector, and amount to approximately 1.33-1.74. Only the retail and services sector is characterised by a smaller mean, which amounts to 1.16 as well as relatively smaller values of norms (0.71-1.57). However, what characterises it is a significantly higher range of all the values observed for the healthcare sector, which falls between 0.09 and as much as 3.25. The ranges for other sectors are clearly tighter.

Table 6. Comparison of descriptive statistics of the operating cash flow coverage ratio for the purchase of fixed assets in the seven sectors under consideration between 2002 and 2017

\begin{tabular}{|l|c|c|c|}
\hline \multicolumn{1}{|c|}{ Sector } & Norm (50\% companies) & Mean & Range (min - max) \\
\hline technologies & $1.490-2.073$ & 1.74 & $0.969-2.924$ \\
\hline healthcare & $0.832-1.897$ & 1.46 & $0.090-3.246$ \\
\hline retail and services & $0.714-1.573$ & 1.16 & $0.384-2.463$ \\
\hline consumer goods & $0.983-2.063$ & 1.67 & $0.607-2.984$ \\
\hline industry and construction & $1.334-2.154$ & 1.68 & $0.728-2.785$ \\
\hline chemicals and raw materials & $1.219-1.836$ & 1.52 & $0.701-2.734$ \\
\hline oil and energy & $1.088-1.665$ & 1.33 & $0.706-2.317$ \\
\hline
\end{tabular}

Source: own classification based on company accounts.

\section{Summary}

In the analysed period, the oil and energy sector was characterised by the greatest efficiency of cash sales and reached, on average, 0.16 pln for every 1 pln in income, reaching the minimal and maximal value at the level of 0.051 and 0.243 , respectively. Mean values of the operating cash flow/sales ratio reached the level of 0.09 in the technologies, as well as chemicals and raw materials sectors. In the former sector, the ratio fell between 0.050 and 0.142 , whereas in the chemicals and raw materials sector it was between 0.042 and 0.139 . This means that in these sectors, each $1 \mathrm{pln}$ of sales brought the companies the income of $0.09 \mathrm{pln}$. The industry and construction sector was characterised by a slightly lower mean value of the operating cash flow/sales ratio in comparison with the sectors of technologies, as well as chemicals and raw materials, reaching the level of 0.07 pln for every 1 pln of income and assuming the minimal and maximal value of 0.043 and 0.098 , respectively. The healthcare, retail and services, as well as consumer goods sectors reached the operating cash flow/sales mean ratio at the level of $0.06 \mathrm{pln}$, with the range (min. and max.) staying at $0.004-0.117,0.031-0.134$, as well as 0.029-0.094 for these sectors.

The operating cash flow/income ratio for the sector of oil and energy also reached the highest level of all the sectors under analysis; its mean value was at 1.05 and its range fell between 0.734 and 1.466. This means that on average for each 1 pln of income from a company's operating activity there was 1.05 pln of operating cash flow. Other sectors that include retail and services, chemicals and raw materials, technologies, healthcare, as well as industry and 
construction had the operating cash flow/income ratio at a similar level, reaching the values of 0.97 pln, 0.96 pln, 0.95 pln, 0.95 pln, as well as 0.92 pln, respectively.

In the analysed period, all the sectors were characterised by similar mean values of the operating cash flow/assets ratio. The sectors of technologies as well as chemicals and raw materials noted the highest mean value of the operating cash flow/assets ratio, which reached the level of 0.11 with the range remaining at $0.065-0.172$, as well as $0.051-0.148$, respectively. This means that within these sectors, each 1 pln invested in assets brought on average $0.11 \mathrm{pln}$ in operating activity-related cash. For each 1 pln invested in assets, the sectors of oil and energy, retail and services, healthcare, consumer goods, as well as industry and construction brought 0.10 pln, 0.09 pln, $0.08 \mathrm{pln}, 0.08 \mathrm{pln}$, as well as 0.08 pln, respectively.

The mean value of the cash flow coverage ratio for repayment of debt in general reached the highest rate in the technologies sector $(0.31 \%)$, and the range of its minimal and maximal value fell between 0.156 and 0.484 . In contrast, for the other sectors, which include retail and services, oil and energy, as well as chemicals and raw materials, a company's cash flow coverage remained at the lowest level, and reached mean values of cash flow coverage at $0.26 \%, 0.25 \%$, as well as $0.23 \%$, respectively. The lowest values of the operating cash flow coverage ratio for repayment of debt in general were noted for the sectors of healthcare, consumer goods, as well as industry and construction; for these sectors, the value was at $0.18 \%$, which means that the analysed sectors are characterised by a relatively low level of corporate operating cash flow in relation to liabilities in general.

The technologies sector for the examined period of time was characterised by the highest mean value of the operating cash flow coverage ratio for the purchase of fixed assets, which was at 1.74 with the range values staying at the level between 0.969 and 2.924. Similar mean values for this particular ratio were achieved by the sectors of industry and construction as well as retail and services; they reached 1.68 and 1.67 , respectively. The other sectors, namely chemicals and raw materials, healthcare, as well as oil and energy reached their mean values at the level of $1.52,1.46$, as well as 1.33 , respectively. The lowest mean value of the analysed ratio was reached by the retail and services sector - it was at the level of 1.16 . This means that all the analysed sectors were characterised by a relatively high capability to finance fixed assets expenditure by cash flows generated by the companies' operating activity.

The quantitative research into the dynamic financial liquidity of companies listed on the Warsaw Stock Exchange, based on intra- and cross-sectoral corporate analysis, forms stage two (following statistical analyses included in stage one [Mosiejko, Bernardelli, Sierant, 2019]) of the evaluation of business security in the short term, associated with the maintenance of financial liquidity at a level that enables business development. According to the authors, what is necessary in order to obtain a complete picture of shaping financial liquidity is further ratio analysis that would include the shaping of net working capital, the cash conversion cycle, debt ratio, and to attempt to get to the bottom of explaining what determines their formation. 


\section{References}

\section{Compact publications}

1. Bannok, G., Manser, W. (1992). Międzynarodowy słownik finansów. Warszawa: Wydawnictwo Andrzej Bojarski.

2. Grzywacz, J. (Ed.), (2015). Finanse przedsiębiorstwa. Decyzje i efekty. Warszawa: Oficyna Wydawnicza Szkoły Głównej Handlowej w Warszawie.

3. Gołębiowski, G. (Ed.), Grycuk, A., Tłaczała, A., Wiśniewski, P. (2014). Analiza finansowa przedsiębiorstwa. Warszawa: Difin.

4. Gołębiowski, G., Tłaczała, A. (2009). Analiza finansowa w teorii i praktyce. Warszawa: Difin.

5. Grabowska, M. (2012). Zarządzanie plynnościa finansową przedsiębiorstw. Warszawa: CeDeWu.

6. Henderson, W., Maness, S. (1989). The Financial Analyst's Deskbook: A Cash Flow Approach to Liquidity. New York: Van Nostrand Reinhold.

7. Jerzemowska, M. (Ed.) (2006). Analiza ekonomiczna w przedsiębiorstwie. Warszawa: Polskie Wydawnictwo Ekonomiczne.

8. Krzemińska, D. (2002). Finanse przedsiębiorstwa. Poznań: Wydawnictwo WSB.

9. Kusak, A. (2004). Płynność finansowa. Analiza i sterowanie. Warszawa: Wydawnictwo Naukowe Wydziału Zarządzania Uniwersytetu Warszawskiego.

10. Maślanka, T. (2008). Przepływy pieniężne w zarządzaniu finansami przedsiębiorstwa. Warszawa: Wydawnictwo C.H. Beck.

11. Michalski, G. (2004a). Definicja i znaczenie krótkoterminowej płynności finansowej, Zarządzanie finansami firm - teoria i praktyka t. 2. Prace Naukowe Akademii Ekonomicznej we Wrocławiu No 1042. Wrocław: Wydawnictwo AE im. Oskara Langego we Wrocławiu.

12. Michalski, G. (2004b). Wartość płynności w bieżacym zarządzaniu finansami. Warszawa: CeDeWu.

13. Nowak, E. (2014). Analiza sprawozdań finansowych. Wyd. 3 zm. Warszawa: PWE.

14. Ostrowska, D., Niedźwiedzka, E. (Ed.) (2015). Podstawy finansów przedsiębiorstw. Warszawa: Difin.

15. Sierpińska, M., Wędzki, D. (2002). Zarządzanie płynnościa finansowa w przedsiębiorstwie. Warszawa: Wydawnictwo Naukowe PWN.

16. Sierpińska, M., Wędzki, D. (2007). Zarządzanie płynnością finansowa w przedsiębiorstwie. Warszawa: Wydawnictwo Naukowe PWN.

17. Wajszczuk, K. (2013). Rachunek przepływów pieniężnych w teorii i praktyce. Program komputerowy: Cash Flow system. Warszawa: Difin.

18. Wędzki, D. (2002). Strategie płynności finansowej przedsiębiorstwa. Kraków: Oficyna Wydawnicza.

19. Wojciechowska, U. (2001). Płynność finansowa polskich przedsiębiorstw w okresie transformacji gospodarki. Aspekty mikroekonomiczne i makroekonomiczne. Warszawa: SGH. 


\section{Papers and studies}

1. Bernardelli, M. (2018). Hidden Markov Models as a Tool for the Assessment of Dependence of Phenomena of Economic Nature. Acta Universitatis Lodziensis. Folia Oeconomica, No. 338(5).

2. Bieniasz, A., Gołaś, Z. (2006). Istota i zróżnicowanie płynności finansowej gospodarstw rolnych. Roczniki Akademii Rolniczej w Poznaniu, No, CCCLXXVII.

3. Michalski, G. (2004). Definicja i znaczenie krótkoterminowej płynności finansowej, Zarządzanie finansami firm - teoria i praktyka t. 2. Prace Naukowe Akademii Ekonomicznej we Wrocławiu, No. 1042.

4. Mosiejko, L., Bernardelli, M., Sierant, A. (2019). Płynność finansowa spółek notowanych na Giełdzie Papierów Wartościowych w Warszawie w latach 2002-2017 w ujęciu sektorowym - część 1. Studia i Prace Kolegium Zarządzania i Finansów, Zeszyt Naukowy, No. 173/2019, Szkoła Główna Handlowa w Warszawie, Oficyna Wydawnicza SGH.

5. Niemiec, A. (2014). Wielkości graniczne statycznych wskaźników płynności finansowej. Zeszyty Teoretyczne Rachunkowości, Vol. 79(135), Stowarzyszenie Księgowych w Polsce.

6. Uyar, A. (2009). The Relationship of Cash Conversion Cycle with Firm Size and Profitability: An Empirical investigation in Turkey, International Research Journal of Finance and Economics, Iss. 24, Retrieved from: www.researchgate.net/publication/290982782Therelatio nhipofcashconversioncyclew ithefirmsizeandprofitabilityAnempiricalinvestigationinTurkey (accessed:10.10.2018). 